This item was submitted to Loughborough's Research Repository by the author.

Items in Figshare are protected by copyright, with all rights reserved, unless otherwise indicated.

\title{
Troubled pasts, collective memory and collective futures
}

PLEASE CITE THE PUBLISHED VERSION

https://www.palgrave.com/us/book/9783319760506

\section{PUBLISHER}

Palgrave Macmillan

\section{VERSION}

AM (Accepted Manuscript)

\section{PUBLISHER STATEMENT}

This book chapter was published in the book Saint-Laurent, C. de, Obradovic, S. and Carriere, K.R. (eds). Imagining Collective Futures: Perspectives from Social, Cultural and Political Psychology. The publisher's website is at https://www.palgrave.com/us/book/9783319760506

\section{LICENCE}

CC BY-NC-ND 4.0

\section{REPOSITORY RECORD}

Tileaga, Cristian. 2018. "Troubled Pasts, Collective Memory and Collective Futures". Loughborough University. https://hdl.handle.net/2134/27971. 


\title{
Chapter 7
}

\section{Troubled pasts, collective memory and collective futures}

\author{
Cristian Tileagă \\ Loughborough University
}

Imagining Collective Futures: Perspectives from Social, Cultural and Political Psychology Constance de Saint-Laurent, Sandra Obradovic \& Kevin R. Carriere

I am grateful to John Wiley \& Sons for permitting me to reproduce and adapt here material published elsewhere. 
Cristian Tileagă is senior lecturer in social psychology at Loughborough University, UK. He has research interests in social memory and transitional justice, social psychology of prejudice and discrimination, and issues around inter-disciplinarity. He is the author of The Nature of Prejudice: Society, Discrimination and Moral Exclusion (Routledge, 2015) and Political Psychology: Critical Perspectives (Cambridge University Press, 2013), and coauthor of Discursive Psychology: Classic and Contemporary Issues (Routledge, 2016) and Psychology and History: Interdisciplinary Explorations (Cambridge University Press, 2014). 
This is a chapter about how nations imagine possible futures in the context of transitional justice and coming to terms with the communist past in Eastern Europe. For postcommunist countries engaged in democratic development the most significant question was that "of the relation of the treatment of the state's past to its future' (Teitel, 2000, p. 3). This chapter focuses on the condemnation of communism in Romania in the Tismăneanu Report and on how the Report is constructing the image of a collective future around the issue of how to represent the communist era into public consciousness.

\section{Transitional justice and prefiguring the future}

Two conceptions of justice have been key to approaching and appraising the relation of the management of the state's past to its future: on the one hand, a universalist conception of justice underpinned by the ideal of comprehensive corrective justice as a sine qua non for full democratic and liberal transformation. On the other hand, a realist conception of justice premised on the close interdependence between law and politics. The idea of full, uncompromising, corrective justice has been perhaps the most influential in fuelling and sustaining strong efforts at re-imagining a national collective future firmly grounded in the development of a distinct social imaginary around an unambiguous representation of Communism as an enemy of human rights. Romania has been the country that advocated this model of corrective justice through the condemnation of communism in the Tismăneanu Report. In doing so, it reimagined, a future ethics of memory based on new democratic values strengthened by the condemnation of communism.

However, I want to argue that this collective re-imagining of communism (and rhetorical construction of a collective future around the idea of transitional, corrective, 
justice) is not devoid of ambivalence; it is not immune to the operations of repression and resistance, especially when related to representing communism as Other, that is, as not reflecting national values and national interests. In this chapter I contend that any cultural and political analysis of imagining of collective post-communist future(s) needs to be able to describe, and engage with, the nature of this ambivalence.

One key aspect of re-imagining of communism in postcommunist countries was centred around the theme of "how we ought to live together in society" (Taylor, 2003, p. 3, my emphasis). The "ought" points to what is yet-to-be, to a yet-to-be-imagined future based on reinterpreting the nature of the communist social order. It is this process of reinterpretation that has been described by historians and political scientists of communism as the greatest challenge postcommunist societies have had to face (Stan, 2006). The various theoretical and practical concerns with lustration, decommunization, restitution of property, retroactive justice and, more generally, with the new political vocabulary of transition, have arisen out of, and received their significance from, the struggles of institutional and individual memory against the background of living with troubled, painful, and difficult pasts. As Stan (2006, p. 383) argues, nations have designed various policy tools

to sift the historical truth from the official lie about the communist past, to identify the mechanisms of repression employed to quash dissent and opposition, to establish the link between the communist party and the political police, to catalogue the manifold crimes of the outgoing regime, and to sort the villains (the communist torturers) from the angels (the victims of the communist regime).

Active, retrospective, revealing acts of remembering have supported policy tools as key means through which injustices can be redressed, victimization and responsibilities recognized, and suffering acknowledged (cf. Tismăneanu, 2008). ${ }^{1}$

\footnotetext{
${ }^{1}$ Historians and political scientists also emphasise the role of socio-structural and political factors that have hindered or limited the reach and significance of these acts of remembering - see, for instance, for the case of
} 
Although these practices have arisen out of demands to engage with troubled and difficult pasts, they were also about imagining collective futures. National collective memory is retrospective as well as prospective (it is about what has been, but also about what has not been yet realized). In imagining collective futures, forging national collective memory was fuelled by the tension between on the one hand, the optimism of betterment brought about by democratic changes and on the other hand, the pessimism of some at seeing the disappearance of familiar social landmarks.

As other contributors to this volume have shown (see de Saint-Laurent, and Bresco, in this volume) past, present, and future are put in circular dialogue by individuals, groups, communities and nations. Whilst postcommunist nations were driven irresistibly into the future, their face was, arguably, still turned toward the past. Benjamin's image of the angel of history neatly captures this impossible quandary:

his face is turned toward the past. Where a chain of events appears before $u s$, he sees one single catastrophe, which keeps piling wreckage upon wreckage and hurls it at his feet. The angel would like to stay, awaken the dead, and make whole what has been smashed. But a storm is blowing from Paradise and has got caught in his wings; it is so strong that the angel can no longer close them. This storm drives him irresistibly into the future to which his back is turned, while the pile of debris before him grows toward the sky. What we call progress is this storm.

Eiland \& Jennings (2003, p. 392, emphasis in original)

Romania, Grosescu and Fijalkowski (2017) on the influence of legal culture, and Gussi (2017) on the role of the timing of transitional justice measures. 


\section{Troubled pasts, collective futures, and mnemonic imagination}

One cannot fully understand how past, present, and future are put in circular dialogue by individuals, groups, communities and nations without engaging with the relationship between imagination and memory. As Zittoun \& Gillespie (this volume) argue, from a sociocultural perspective, imagination is "a deeply sociocultural phenomenon, in its origin, mediation and consequences". That is very much true for memory, as it is for other psychological phenomena. Memory manifests itself and takes various forms at different levels of social and political organization, in public and in private, in elite discourse and in lay meanings, in the guise of personal as well as societal remembering.

As Keightley and Pickering (2012) note, imagination and memory are intertwined resources for making sense of experience: "imagination is vital in reactivating memory, and memory is vital in stimulating imagination" (p. 51). Keightley and Pickering use the notion of "mnemonic imagination" to refer to the relationship between remembering that "draws upon certain symbolic resources ... and is in itself intrinsic to cultural processes of one kind or another" (p. 82), and imagination through which we "develop a sense of the temporal relations between different experiences, different episodes and different stages in our lives" (p. 51).

Keightley and Pickering describe the workings of individual memory and individual imagination. I argue that their argument can be extended when engaging with collective memory and collective imagination. Remembering communities (in this specific case, postcommunist nations) engage in numerous "temporal transactions" and imaginative reconstructions in order to produce a nationally relevant collective story. In the context of transitional justice, nations connect memory and imagination through socially and politically organised practices (lustration, decommunization, truth and reconciliation, etc.). The 
emerging mnemonic imagination (and the emerging narrative) is seen as providing "the conditions for transformative action in the present oriented towards an anticipated future" (Keightley and Pickering, 2012, p. 75). It can be argued that imagination, and not only memory, is multidirectional (cf. Rothberg, 2009). Imagination, as does memory, points in different directions, serves different functions, and operates beyond concerns with truthfulness of perspectives.

One relevant example comes from the troubled history of reconciliation in South Africa. The main purpose of the Truth and Reconciliation Committee was to imagine the collective future of interethnic relations based on a collective narrative. However, as Andrews (2007) shows in the context of testimonies and responses to the Truth and Reconciliation Commission (TRC) there was no unique or collective narrative model that was used by all of the social actors. Although citizens recounting tales of suffering represented a unique (and successful) model of rebuilding a "broken" nation, it was far from being a uniform one, with different stories being told, sometimes as the result of pressures on victims to tell certain kinds of stories while testifying, or as the outcome of different experiences and perspectives of victims and perpetrators, and various other individuals and groups challenging official versions of the past and demanding redress. As Andrews argues, the concern of the TRC focused on the creation of acceptable, believable, pragmatic versions of memory more than on the truthful collective memory, and therefore on developing realistic and usable images of the past history of race relations rather than truthful ones.

It can be argued that the diversity of these acceptable, believable, pragmatic, accounts testifies to an active interrelationship between memory and imagination. We know that memories that are articulated out of living with a difficult and sometimes contested past (Byford and Tileaga, 2017; Brown and Reavey, 2015) should not be seen simply as truthful 
accounts but instead involving imaginative reconstructions in "terms of what is being recollected and its significance for ongoing identification with self and others." (Brown and Reavey, 2013, p. 55). Moreover, another key role of imaginative reconstructions is to symbolically align past, present and future, and create a sense of collective continuity.

\section{Case background}

In the majority of former communist states reckoning with a troubled and painful communist past has presupposed a strong dimension of recuperation and reassessment of communist memory and history through empowering the victims, identifying the victimizers, and revealing the nature and the extent of crimes and abuses perpetrated by the defunct communist regime (Tismăneanu, 2008). The official condemnation of the communist regime in Romania in the so-called "Tismăneanu Report," that is, the final report of the Presidential Committee for the Analysis of the Communist Dictatorship in Romania chaired by Professor Vladimir Tismăneanu, was a peculiar case in point. As an initiative unmatched by any other Central and Eastern European country except Germany, which constituted two history commissions in 1992 and 1994, the Committee set out to give a definitive account of the crimes and abuses of communism in that country (1945-1989). ${ }^{2}$ The avowed ambition of the Tismăneanu Report was to provide a synthetic and rational account of the history of communism and, in doing so, to facilitate the creation of a unified collective memory of communism capable of overriding any competing individual or community experiences/perspectives (Tismăneanu, 2007a).

The leading author of the Report was Vladimir Tismăneanu, an internationally renowned expert (political scientist and historian) of communism. The Report consisted

\footnotetext{
${ }^{2}$ For more details on the structure, scope and reactions to the Tismaneanu Report, see Ciobanu (2009), Cesereanu (2008) and Tismăneanu (2007a).
} 
largely of an account of communism's political methods and institutions. It aimed at documenting the repressive and criminal nature of the totalitarian society and giving an exhaustive account of communism as a self-perpetuating political system. In December 2006, in front of the Romanian Parliament, the then president Traian Băsescu, officially condemned the crimes and abuses of the communist regime, declaring communism as "illegitimate" and "criminal." This is demonstrated by the following three excerpts from the Report:

\section{Excerpt 1}

"Condemning communism is today, more than ever, a moral, intellectual, political, and social duty/obligation. The democratic and pluralist Romanian state can and ought to do it. Also, knowing these dark and saddening pages of 20th century Romanian history is indispensable for the younger generations who have the right to know the world their parents lived in."

\section{Excerpt 2}

"Against the facts presented in this report, it is certain that genocide acts have been committed during 1945-1989, and thus the communist regime can be qualified as criminal against its own people."

\section{Excerpt 3}

"Taking act of this Report, the President can say with his hand on the heart: the Communist regime in Romania was illegitimate and criminal."3

As I showed elsewhere (Tileagă, 2009), by emphasizing the criminality and illegitimacy of the communist regime, the Report creates, affirms, and legitimates a narrative for a normative ethics of memory that transmits moral responsibilities to new generations. In doing so, it projects, and imagines, a future ethics of memory based on the values underpinned by the condemnation of communism. The act of condemnation itself is offered as a foundational moment for an alternative ethics of memory and justice.

\footnotetext{
${ }^{3}$ Report, pp. 35-36, 211, and 776, respectively.
} 


\section{Preempting the future: time and national identity}

The Report and the president's address clearly mark the boundaries of the 'event', i.e., 'state of affairs' under scrutiny. There is a clear temporal delineation of the period: 1945-1989. The period is described in different ways: in the Report, it is being referred to as 'four decades and a half of obsessive following in the construction of an impossible utopia'; in the president's address, it is described as 'a grim chapter in our country's past'.

Yet the Report does not solely rely on the temporal delineation of its 'object of inquiry'. As some authors have argued, the politics of coming to terms with the past "consists first and foremost in structuring time" (Santiso, 1998, p. 26). The focus on the present, the past and the future is said to frame and establish the boundaries of moral and political courses of action. In political discourse (as in ordinary talk), "time is a resource ... to be drawn on ... in order present an identity, establish a truth or defend an interest" (Taylor \& Wetherell, 1999, p. 39). In this particular case, the structuring of time is achieved by joining a political agenda (of condemnation and reconciliation) and preempting the future of the nation. This is a feature of both the Report and president's address:

\section{Excerpt 4}

"The moment has finally come for this methodically maintained state of amnesia to end. The recuperation of memory, as well as the identification of responsibilities is indispensable to the workings of a democratic political community" (Report, p. 10).

\section{Excerpt 5}

"The moment has come to identify the nature and the legacies of the communist regime" (Report, p. 626)

\section{Excerpt 6}

"17 years after the December 1989 revolution, the moment has fully arrived for all the communist archives to be made public and accessible" (Report, p. 640) 


\section{Excerpt 7}

"The imported communism we experienced in our own lives for five decades is an open wound in the history of Romania whose time to heal has come once and for all" (President's address)

\section{Excerpt 8}

"We believed that we could forget communism, but it did not want to forget us. Therefore, the condemnation of this past arises as a priority for the present, without which we shall behave in the future too in a way which resembles the burden of an unhealed illness" (President's address)

The pragmatic actions identified by the Report and the president are presented as actions stemming from an authoritative collective time summon (cf. Leeuwen, 2005). As Billig (1998) has argued, "the construal of time is crucial to ideology" (p. 209). The time for coming to terms with the past points reflexively to a political agenda that is rhetorically structured to work against the 'ambivalence' of previous political positions, such as avoiding or refusing to come to terms with the past.

Moreover, closing a chapter in the nation's history entails a 'healing' process: the closing of an 'open wound' and alleviating 'the burden of an unhealed illness'. The message of both Report and president's address seems uncontroversial: the future (of the nation) depends on a clean, and immediate, break with the communist past. Together with the other features identified in the Report and president's address (see Tileaga, 2009), it provides the ethical grounds for the implementation of moral/political/legal courses of action.

Condemnation and reconciliation are constituted as activities that embody the values and goals that the Romanian nation aspires to. Condemnation and reconciliation are presented as an integral part of the political project of the nation. As other examples show, they are constitutive of both 'future action and future reality' (Dunmire, 2005, p. 484): 


\section{Excerpt 9}

"The future of Romania is dependent upon assuming its past, that is upon condemning the communist regime as enemy of the human race. Not doing it, here and now, will forever burden us with the guilt of complicity, be it only through silence, with the totalitarian Evil" (Report, p. 19)

\section{Excerpt 10}

"This symbolic moment represents the balance sheet of what we have lived through and the day in which we all ask ourselves how we want to live henceforward" (president's address)

There are two significant ideological aspects in all these excerpts. On the one hand, there is a clear progressive promise of national change and transformation clearly tied to a repertoire of national progress. ${ }^{4}$ It would seem that a close adherence to this political agenda would give the 'assurance' that moral transformation is irreversible, and that it would be 'no longer possible ... to fall back into the past' (Habermas and Michnik, 1994, p. 11). In conjunction with the other characteristics of communism ('illegitimate' and 'criminal'), the Report reflexively positions communism as an 'evil' political ideology. On the other hand, communism is described as an 'evil' outsider - it is distanced from the national self. There is an active resistance in engaging with collective imagining of the contested space of the popular memory of communism. The Report's own resistance to, and avoidance of, an alternative, collective imagining of communism privileges "a particular future ... over alternative futures" (Dunmire, 2005, p. 486).

\footnotetext{
4 'In narratives of national progress in which time is constructed as a forward movement or flow, there is an implied determinism, or, more colloquially, the notion of fate or destiny' (Taylor and Wetherell, 1999, p. 51)
} 


\section{Communism as the Other}

In the remainder of this chapter I want to argue that this ambivalence in the Report stems from an unresolved tension between wishing to express the uniqueness of a troubled and painful past and wishing to repress unwanted and shameful experiences that may point in the direction of perceiving communism as a genuine national experience. The Report's attitude toward communism (as not 'us': "foreign import", "illegitimate", and, ultimately, "criminal") can be seen as part and parcel of a broader set of social practices that, I argue, are relevant to understanding the official appraisal of communism in public consciousness. Drawing upon Billig's (1999) work on “social repression" and Frosh's (2010) notion of "resistance”, I call these practices "social practices of avoidance” (cf. also Tileagă, 2017). Billig's account of repression stresses the importance of social practices of "avoidance" that are part and parcel of conversational practices of society around topics or feelings that are too "difficult" to discuss. Resistance refers to "something to be overcome"; analysis is a process of understanding the mind that is "at war with itself, blocking the path to its own freedom." (Rose, 2007, p. 21 apud Frosh, 2010, p. 166).

As I intimated elsewhere (Tileagă, 2017) the Report fails to resolve the foundational problem that is facing any historical inquiry into troubling and difficult pasts. This idea is expressed by LaCapra (1994) who writes about the need to reconcile "the relation between the requirements of scientific expertise and the less easily definable demands placed on the use of language by the difficult attempt to work through transferential relations in a dialogue with the past having implications for the present and future." (p. 66)

LaCapra (1994, p. 4) distinguishes between "constative" historical reconstruction and "performative" dialogic exchange with the past. As he argues, this latter "performative" dialogic exchange relies on certain unconscious memory activities. The process of 
canonization of a single, and all-encompassing, collective narrative around the nature of communism in Romania has been, predominantly, a constative historical reconstruction based on the archival, factual, reconstruction of experiences. However, as I showed elsewhere (see Tileagă, 2017), this constative historical reconstruction encapsulates distinctive practices of avoidance.

Perhaps the most striking illustration of avoidance is tied to the imaging of communism as the Other in the Report. As I have also shown elsewhere (see Tileagă, 2009 and 2012), communism is described in general terms throughout the Report as a "regime" and an "ideology," a "utopian conception," an "enemy of the human race" that instituted "the physical and moral assassinate," and survived "through repression." However, communism is also described in national terms: a "(foreign) occupation regime," "criminal towards its own people," and "antinational," among others. In doing so, the Report is proposing a specific method of reasoning about Romanian history and memory that constitutes communism as the Other, not quite "us." Interestingly, the narrative of communism is not self-condemnatory or self-blaming, but rather communism is distanced from (the national) self. This is demonstrated by the following excerpts: 
"The total Sovietisation, through force, of Romania, especially during the period 1948-1956, and the imposition under the name 'dictatorship of the proletariat' of a despotic political system ruled by a profiteering caste (nomenklatura), tightly united around its supreme leader."

\section{Excerpt 12}

"Pretending to fulfill the goals of Marxism, the regime has treated an entire population as a masse of lab mice part of a nightmarish social engineering experiment."

\section{Excerpt 13}

"...the imposition of a dictatorial regime totally surrendered to Moscow and hostile to national political and cultural values"

Excerpt 14

"The Romanian Popular Republic, who has come into being through diktat, or more exactly, through a coup d'état, symbolizes a triple imposture: it wasn't even a Republic (in the full sense of the phrase), it wasn't popular, and, most certainly, it wasn't Romanian."

Moreover, the communist regime is also found "responsible" of crimes "against the biological makeup of the nation." Through references to physical and psychological effects (for example, "psychological weakening and disheartenment of the population," and “decreased capacity for physical and intellectual effort") ${ }^{6}$ communism is externalized and objectivized (Leeuwen, 1995) as a sui generis political ideology designed to undermine the Romanian ethos. The Report describes communism as "antipatriotic," whereas the Romanian communist leaders are portrayed as lacking "patriotic sentiments," and Romanian communist politics are described as not representing the affirmation of a "patriotic spirit/will.",

Paradoxically, the basic premise for the condemnation of Romanian communism is to construe communism as the Other, in other words as not reflecting Romanian values and national interests. This position can be said to reflect an active avoidance of the implication

\footnotetext{
${ }^{5}$ Report, pp. 774, 775, 774, 765, respectively.

${ }^{6}$ Report, p. 461-462.

${ }^{7}$ Report, p. 765, 773, 30, respectively. cf. also Tileagă, 2009
} 
that communism may have been in any way a "criminal" ideology that reflected, and furthered, national interests. The textual construction of the negative qualities of communism in the Tismăneanu Report (“enemy of human rights," "illegitimate," and "criminal”) opens the way for the operation of social repression, the suppression of the socially inappropriate thought that communism may have been historically part and parcel of national identity. The negative attributes of communism are distanced from the (national) self. The Report actively resists alternative ideological implications, especially those that closely reflect nationalist representations of communism in popular culture. As Frosh notes, resistance is a useful notion to understanding the subtleties of ambivalence. "Resistance," Frosh points out, "has general significance as a way of indicating how a person might want something but not want it at the same time." $(2010$, p. 167)

The Romanian post-communist transition has developed its own complex social conventions and discursive codes that resist and repress the issue of collective involvement in the perpetuation of the communist system. By constructing communism as the Other, paradoxically, even progressive texts such as the Tismăneanu Report are engaging in collective avoidance of this very sensitive issue at the heart of successful transitional justice. By positioning communism on the outside, the Report actively represses a performative dialogic exchange with the past and collective imagining of the contested space of the popular memory of communism.

The basis of a performative dialogic exchange with the past, as LaCapra argues, is rooted in the notion of "working-through" taken-for-granted ethical and political considerations. $^{8}$ By stifling mnemonic imagination the Report is resisting the forging of (new) transactional relationships between past and present that fall outside the tried-andtested interpretive schemas of the professional historian and political scientist of communism.

\footnotetext{
${ }^{8}$ As LaCapra continues, "working-through implies the possibility of judgment that is not apodictic or ad hominem but argumentative, self-questioning, and related in mediated ways to action.” (1994, p. 210).
} 
As Keightley and Pickering remind us "forging transactional relationships between past and present necessitates the past being available for new uses in an ever-changing present, and this involves not only reflexively considering the past from our own perspective but also imaginatively engaging with the relations which others might have with particular pasts, or how they might view our own relations to the past" (2012, p. 178)

As new generations of young people participate in the public debate on the nature of communism, they acquire specific routines of thought, and in addition they learn the accepted and acceptable social conventions and discursive codes that present communism, and its legacy, as the Other (not "us"!). Building a mnemonic community implies a process of formal, as well as informal, mnemonic socialization. According to the Report, the idea that "we" (Romanians) may have had anything to do with the perpetuation of the communist regime must be suppressed from national consciousness. It can be argued that the Report fails as a tool of mnemonic (political) socialization. Unlike other instruments of political socialization (e.g. national museums dedicated to the legacy of communism in eastern Europe - House of Terror (Budapest) or Memorialul Sighet (Sighet), explicitly designed to accomplish the goals of mnemonic socialization, that is, socialization into particular images (of genocide), memories (of victimhood), and narratives (of redemption) about the past, present and future of the nation, the Report engages with the communist past in the absence of mnemonic imagination.

By making official narratives more accessible, and by bringing vernacular narratives to the surface, museums become sites where both consensus, as well as contestation, resistance, around national and local history can take shape. In contrast, the Report seems to downplay social factors, social frameworks, and social relations that make social remembering and social imagination possible by prioritizing disciplinary allegiance and expert knowledge. The Report champions the perspective of the professional 
historian/political scientist to understanding and interpreting a troubled and difficult recent past. It champions a privileged, closed system for describing the world. In the Report, the contingent, context-related and context-dependent emergence of social memory is contrasted with the (presumed) stability and permanence of historical archives. "Self-sufficient" professional research endeavours, to use LaCapra's (2001) term, are usually extremely effective in shielding canonical ideologies and images from the impact, contradictions, and unforeseen consequences brought about by mnemonic imagination.

\section{Conclusion}

The fall of communism has propelled nations forward, into an exciting, yet uncertain future; however, nations are still finding it very difficult to "move on", to leave the past behind. "One wants to get free of the past," Adorno observed, "one cannot live in its shadow," but the "past one wishes to evade is still so intensely alive."(Adorno, 1986, p. 115).

Prefiguring the future of postcommunist nations has entailed a strong dimension of, and engagement with, retrospective and transitional justice. The conventional approach, that of "telling the truth" about the past and making it public, is believed to enlighten people and change perceptions. "Telling the truth" about the past is also seen as a progressive attempt to stifle and "control" returns of "negative currents" (for example, revisionist accounts and nostalgia), to bring the "repressed" oppressive ideology and effects of communism into public consciousness, and thus to banish the risk (and fear) of repetition. Yet, at the same time, as I attempted to demonstrate in this chapter, the same, progressive, conventional approach based on "telling the truth" can mask and repress an insufficiently worked-through

\footnotetext{
${ }^{9}$ As Tismăneanu himself acknowledges: "For me, as historian and political scientist, the verdict of such a commission was not needed in order to argue that 'communism has been an aberrant system, criminal, inhuman' (Tismăneanu, 2007b). For the professional historian, like Tismaneanu, communism is both an object of loathing and desire. A process of "canonization" of a unique representation of recent history requires that alternative experiences, perspectives, and interpretations are actively suppressed.
} 
transferential relation with a controversial past by turning it into an obstacle to fulfilling the avowed goals of social justice. In this chapter I have shown how the Tismăneanu Report condemning communism in Romania feeds the illusion that transitional justice can be "fixed for all time" (Teitel, 2000). Thus, it obscures, masks, and suppresses, as much as it reveals, key ideological aspects of the appraisal of communism in public consciousness.

This position should not be seen as denying the significance and overall social value of the conventional ways in which historians or political scientists approach the issue of coming to terms with the recent communist past. Historical knowledge of the objective (ideological) makeup of political regimes and other social formations should be continually sought as a remedy for half-truths, political manipulation, or simply ignorance. Yet, such knowledge, when used and reproduced as a "matter of fact," is arguably inadequate with regard to the handling of dilemmas and ambiguities of collective memory or to the development of broader social scientific frameworks of analysis. One needs to strive to find the meaning of the collective memory of communism in the sometimes contradictory, paradoxical attitudes and meanings that members of society uphold and negotiate, and not only in and through official representations of recent history "compressed into generalities." (Veyne, 1984, p. 63).

LaCapra rightly argues, "the after effects ... of traumatic events are not fully owned by anyone and, in various ways, affect everyone" (2001, p. xi). The fixation on a single, unique, all-or-nothing description of the nature of (Romanian) communism in the Tismăneanu Report has led, perhaps not surprisingly, to resistance. Political scientists have shown that transitional justice policies based on an all-or-nothing description of the nature of (Romanian) communism have only offered "partial justice, and therefore constituted a politically feasible and morally defensible solution that was, nevertheless, far from being 
perfect." (Stan, 2006, p. 385). One could go even further and claim that any hope of full mastery of historical events, of the "last word", is a regressive step.

As Billig (1997) argues, when one engages in ideological analysis one shifts the focus from the individual unconscious to the social and collective constitution of the unconscious. Romania has sustained a strong, unfailing commitment to meaningful, official and unofficial memory and identity projects of coming to terms with the communist past. It has overcome numerous barriers and, over the years, it has created a "vigilant critical culture" (Nussbaum, 2013, p. 124) that has supported transitional justice, and the continuation of liberal and democratic values. This vigilant critical culture, however, is not devoid of ambivalence; it is not immune to the operations of repression and resistance. One key foundation of this ambivalence is an active resistance in engaging with a collective reimagining of the contested space of the popular memory of communism (by distancing communism from the national self) set against a progressive promise of social justice.

There is a need to excavate the nature of this ambivalence, to unearth more of the nature of repression and resistance that may stand in the way of a full understanding of social and transitional justice. Without exploring the nature of this ambivalence fully, there is the risk that this, progressive, vigilant critical culture will be at odds and greatly out of synch with other active, progressive, social imaginary currents in society. This, progressive, vigilant critical culture cannot hope to fulfil both a formative, as well as normative, mnemonic socialization function (cf. Connerton, 1989) without engaging directly with the mnemonic imagination that feeds the collective imagining of the contested space of the popular memory of communism. Moreover, without exploring the nature of this ambivalence fully this vigilant critical culture will find it very difficult to fight some of the most enduring and pernicious myths of, and obstacles to, transitional justice, namely that "political justice is political vendetta" and that "justice is unnecessary" (cf. Stan, 2006). 
The question of how to take communism into public consciousness remains the greatest political, epistemological, and ethical challenge facing postcommunist states. One other important challenge is finding appropriate responses to ambivalence by fostering a renewed mnemonic imagination of communism. If, as Keightley and Pickering argue, imagination and memory are to be conceived as intertwined resources for making sense of experience, then one must ensure that the two are brought into close contact, that they are used to explore the (communist) past through the lens of possible or alternative futures.

The imperative of a "shared memory" entails the "integration" and "calibration" of different perspectives and stances (Margalit, 2002). This means, primarily, the integration and calibration of what is not yet worked-through, of ambivalent and suppressed meanings. It also means the integration and calibration of mnemonic imagination that envisages alternative possible collective futures. Imaginative, performative, reconstructions of a troubled and contested past can enable individuals, as well as communities and nations, to "turn around" on their schemata, to "reshuffle their constituent elements" (Keightley and Pickering, 2012, p. 57) in order to reposition themselves differently within the circular cycle of past, present and future. 


\section{References}

Adorno, T. (1986) What does coming to terms with the past mean? (trans. Bahti T, Hartman G). In Hartman G (ed.) Bitburg in moral and political perspective (pp.114-129). Bloomington: Indiana University Press.

Andrews, M. (2007) Shaping history: Narratives of political change. Cambridge: Cambridge University Press.

Billig, M. (1997) Discursive, rhetorical and ideological messages. In C. McGarty and S.A. Haslam (eds) The message of social psychology (pp. 36-53). Oxford: Blackwell. Billig, M. (1999) Freudian Repression. Cambridge: Cambridge University Press.

Bresco (this volume) Narratives and prolepsis. C. de Saint-Laurent, S. Obradovic \& K. Carriere (eds) Imagining Collective Futures: Perspectives from Social, Cultural and Political Psychology (pp. **_**). Springer International Publishing.

Brown, S.D. \& Reavey, P. (2013) Experience and memory. In E. Keightley and M. Pickering (eds) Research methods for memory studies (pp. 45-59). Edinburgh: Edinburgh University Press.

Brown, S.D. \& Reavey, P. (2015) Vital memory and affect: Living with a difficult past. London: Routledge.

Byford, J. \& Tileagă, C. (2017) Accounts of a troubled past: Psychology, history, and texts of experience. Qualitative Psychology, 4, 101-117.

Cesereanu, R. (2008) The Final Report on the Holocaust and the Final Report on the Communist dictatorship in Romania. East European Politics and Societies, 22, 270-28. Ciobanu, M. (2009) Criminalising the past and reconstructing collective memory: The Romanian Truth Commission. Europe-Asia Studies, 61, 313-336.

Connerton, 1989 
de Saint-Laurent (this volume) Imagination and temporal heteroglossia. C. de Saint-Laurent, S. Obradovic \& K. Carriere (eds) Imagining Collective Futures: Perspectives from Social, Cultural and Political Psychology (pp. **_**). Springer International Publishing.

Eiland, H. \& Jennings, M. (eds) (2003) Walter Benjamin: Selected writings (volume 4: 19381940; translated by Edmund Jephcott and others). Cambridge, MA: Harvard University Press.

Frosh, S. (2010) Psychoanalysis outside the clinic: Interventions in psychosocial studies. Basingstoke: Palgrave Macmillan.

Grosescu, R. \& Fijalkowski, A. (2017) Retrospective justice and legal culture. In L. Stan and L. Turcescu (eds) Justice, memory and redress in Romania: new insights (pp. 100-123). Cambridge: Cambridge Scholars Publishing.

Gussi, A. (2017) Paradoxes of delayed transitional justice. In L. Stan and L. Turcescu (eds) Justice, memory and redress in Romania: new insights (pp. 76-99). Cambridge: Cambridge Scholars Publishing.

Keightley, E. \& Pickering, M. (2012) The mnemonic imagination: Remembering as creative practice. Basingstoke: Palgrave

Keightley, E. \& Pickering, M. (2013) Painful pasts. In E. Keightley and M. Pickering (eds) Research methods for memory studies (pp. 151-166). Edinburgh: Edinburgh University Press.

LaCapra, D. (1994) Representing the Holocaust: History, theory, trauma. Ithaca: Cornell University Press.

LaCapra, D. (2001) Writing history, writing trauma. Baltimore, MD: Johns Hopkins University Press.

Margalit, A. (2002). The ethics of memory. Cambridge, MA: Harvard University Press. 
Rose, J. (2007) The last resistance. London: Verso.

Rothberg, M. (2009) Multidirectional memory: Remembering the Holocaust in the age of decolonization. Stanford: Stanford University Press.

Stan, L. (2006) The vanishing truth: Politics and memory in post-communist Europe. East European Quarterly, 40, 383-40.

Taylor, C. (2003) Modern social imaginaries. Duke University Press.

Teitel, R. (2000) Transitional justice. Oxford: Oxford University Press

Tileagă, C. (2009) The social organization of representations of history: The textual accomplishment of coming to terms with the past. British Journal of Social Psychology, $48,337-355$.

Tileagă, C. (2012) Communism in retrospect: The rhetoric of historical representation and writing the collective memory of recent past. Memory Studies, 5, 462-478.

Tileagă, C. (2017) Conceptions of memory and historical redress. In L. Stan and L. Turcescu (eds) Justice, memory and redress in Romania: new insights (pp. 2-23). Cambridge: Cambridge Scholars Publishing.

Tismăneanu, V. (2007a) Confronting Romania's past: A response to Charles King, Slavic Review, 66: 724-727.

Tismăneanu, V. (2007b) Refuzul de a uita: articole şi comentarii politice (2006-2007). Bucharest: Curtea Veche.

Tismăneanu, V. (2008) Democracy and memory: Romania confronts its communist past. Annals of the American Academy of Political and Social Science, 617, 166-180.

Tismăneanu, V., Dobrincu, D. and Vasile, C. (2007) Comisia Prezidentiala pentru Analiza Dictaturii Comuniste din Romania. Raport Final [Final Report: The Presidential Committee for the Analysis of Communist Dictatorship in Romania]. Bucharest: Humanitas. 
van Leeuwen, T. (1995) Representing social action. Discourse \& Society, 6, 81-106.

van Leeuwen, T. (2005) Time in discourse. Linguistics and the Human Sciences, 1, 127-145.

Veyne, P. (1984) Writing history: Essay on epistemology (translated by Mina Moore-

Rinvolucri), Middletown, Connecticut: Wesleyan University Press.

Zittoun \& Gillespie (this volume) Imagination from a sociocultural perspective. C. de SaintLaurent, S. Obradovic \& K. Carriere (eds) Imagining Collective Futures: Perspectives from Social, Cultural and Political Psychology (pp. **_**). Springer International Publishing. 